УДК 376.141+612.224.2

DOI 10.11603/me.2414-5998.2019.3.10650

Н. В. Пасєчко

ORCID 0000-0002-2081-4269

ResearcherID Q-4840-2016

Scopus Author ID 6504311065

Н. I. Ярема

ORCID 0000-0002-4378-1084

ResearcherID Q-7395-2016

Scopus Author ID 6508250925

I. В. Смачило

ORCID 0000-0003-4323-8628

ResearcherID Q-4852-2016

Scopus Author ID 57195557028

I. П. Савченко

ORCID 0000-0002-9687-1219

ResearcherID Q-4858-2016

ДВНЗ «Тернопільський державний медичний університет

імені І. Я. Горбачевського МОЗ Украӥни»

\title{
СИМУЛЯЦІЙНІ МЕТОДИКИ У ВИРІШЕННІ БАГАТОРІВНЕВИХ СИТУАЦЙНИХ ЗАДАЧ У ІІ ЕТАПІ ВСЕУКРАЇНСЬКОЇ СТУДЕНТСЬКОЇ ОЛІМПІАДИ 3 ЕНДОКРИНОЛОГІЇ
}

\author{
N. V. Pasyechko, N. I. Yarema, I. V. Smachylo, I. P. Savchenko \\ I. Horbachevsky Ternopil State Medical University \\ SIMULATIVE METHODS IN SOLUTION OF THE MULTILEVEL \\ SITUATION TASKS IN THE STAGE II OF UKRAINIAN STUDENT'S \\ OLYMPIAD IN ENDOCRYNOLOGY
}

\begin{abstract}
Анотація. У статті наведено сучасну методику проведення II етапу Всеукраїнської студентської олімпіади з ендокринології з використанням симуляційних методик. 3 метою залучення студентів до активної наукової роботи, мотивування у кожного інтелектуальних здібностей, розвитку комунікативних рис використовувалась оцінка теоретичних знань у вигляді тестових завдань, розв'язання ситуаційних задач, інтерпретація лабораторних та інструментальних методів обстежень, а також вирішення змодельованого невідкладного стану в інтерактивному режимі. Відбувалася студентська олімпіада з ендокринології в чотири тури: I - написання тестових завдань, II - розв’язання ситуаційних задач підвищеної складності, III - вирішення змодельованого невідкладного стану в інтерактивному режимі, IV - вирішення практичних завдань з інтерпретації лабораторно-інструментальних методів обстеження. Від студентів-учасників вимагався синтез знань з ендокринології, отриманих не лише за роки вивчення даної дисципліни у вищих навчальних закладах, але й суміжних дисциплін, таких, як кардіологія, фармакологія, лабораторна та інструментальна діагностика. Особливе місце в підготовці олімпійця з ендокринології займало вміння застосування стандартів семіотики та лікування при роботі з віртуальним пацієнтом. За кількістю набраних балів переможцями студентської олімпіади 3 ендокринології стали учасники із Тернопільського державного медичного університету ім. I. Я. Горбачевського (I місце), ІваноФранківського національного медичного університету і Сумського державного медичного університету (II місце), а також Львівського національного медичного університету ім. Д. Галицького та Київського медичного університету і Дніпропетровської медичної академії (III місце).

Вирішення змодельованого невідкладного стану в інтерактивному режимі дозволяє розвинути у студента швидкість клінічного мислення та надання невідкладної допомоги хворому при різних клінічних станах.
\end{abstract}

Ключові слова: симуляційна методика; інтерактивний режим; тестовий контроль; ситуаційні задачі; практичні навички.

Abstract. The article presents a modern methodology of the conducting the stage II All-Ukrainian Student’s Olympiad by using the simulation techniques. There was the using of evaluation the theoretical knowledge such a test tasks, the solution of situational tasks, the interpretation of the laboratory and instrumental methods of examination and also the solution the modified emergency condition in

(ㄱ Н. В. Пасєчко, Н. І. Ярема, І. В. Смачило, І. П. Савченко 
the interactive mode for the purpose students to engage the active scientific work, motivation for each intellectual abilities, development of their communicative qualities. The Student's Olympiad was passed in the four tours: I - writing the test tasks, II - solution the situation tasks with increased complexity, III - solution the modified emergency condition in the interactive mode, IV - solution the practical tasks with interpretation the laboratory and instrumental methods of examination. The students were required the synthesis not only the endocrinology knowledge, getting during the studying in the university, but also the related disciplines, such as cardiology, pharmacology, laboratory and instrumental diagnostics. The main place in the preparation the student was taken the skill, using of semiotics standard and treatment during the working with the virtual patient. The winners in the stage II of All-Ukrainian Student's Olympiad in Endocrinology with the most scored points became the participants from I. Horbachevsky Ternopil State Medical University (I place), Ivano-Frankivsk National Medical University and Sumy State Medical University (II place), and also Lviv National Medical University and Dnipropetrovsk Medical Academy (III place).

The solution of the modified emergency condition in the interactive mode will allow students to develop the speed of clinical thinking and to provide the urgent care to the patient in different clinical conditions.

Key words: simulation technique; interactive mode; test control; situational tasks; practical experience.

Вступ. На сьогодні провідним напрямком освітнього процесу студентів у вищих навчальних закладах вважають відвідування практичних занять, лекцій, складання заліків та іспитів, отримання позитивних оцінок як результат засвоєння отриманої інформації. Проте розкриття інтелектуального потенціалу студентів та розвиток їх пізнавальної діяльності вимагають більш поглибленого вивчення певних аспектів медицини [3]. Саме студентська олімпіада є потужним змаганням інтелектуальних вмінь, що дає можливість студентам продемонструвати своє клінічне мислення та оцінити якість різних методик навчання [2].

Згідно $з$ даними низки авторів [2-4, 7], предметна олімпіада $є$ найбільш ефективною формою стимуляції професійного росту студента, яка містить у собі елементи не лише навчального, а й дослідницького характеру. Поряд із формуванням у студентів інтересу до наукової роботи з певної спеціальності олімпіада формує також їх життєву позицію [7].

Окрім того, студентська предметна олімпіада допомагає розв'язати такі завдання [3, 4]: виявити обсяг знань, умінь, аналізу, синтезу та оцінки заданої інформації; встановити рівень навченості студентів; виявити орієнтацію студентів в активізації знань.

Мета статті - підвищити ефективність проведення II етапу Всеукраїнської студентської олімпіади з ендокринології шляхом використання симуляційних методик у вирішенні багаторівневих ситуаційних задач.

Теоретична частина. Основними вимогами, що висуваються до проведення предметної олімпіади на високому методичному та організаційному рівнях, є: якість оцінювання, відкритість та доступність, рівноцінність конкурсних завдань, рівність учасників, наявність в учасників достатнього набору знань та практичних навичок [1]. Саме такі принципи були використані при організації та проведенні II етапу Всеукраїнської студентської олімпіади з ендокринології, яка відбулася 4-5 квітня 2019 р. в ДВНЗ «Тернопільський державний медичний університет імені І. Я. Горбачевського МОЗ України».

Всього у II етапі Всеукраїнської студентської олімпіади 3 ендокринології взяли участь 40 студентів 4-5-6 курсів, переможців I етапу із різних державних та приватних медичних закладів всієї України. Географія учасників охоплювала 13 регіонів, серед яких: Київ, Дніпро, Луганськ, Львів, Запоріжжя, Ужгород, Одеса, Суми, Полтава, Харків, Вінниця, Чернівці, Івано-Франківськ.

Перевіркою та оцінюванням знань студентів на олімпіаді займалося журі, до складу якого увійшли науково-педагогічні працівники вузів (доктори наук) ДВНЗ «Тернопільський державний медичний університет імені I. Я. Горбачевського MO3 України» та з інших навчальних закладів, а саме: д-р мед. наук, проф. Ю. І. Комісаренко, д-р мед. наук, проф. Н. В. Пашковська, канд. мед. наук, доц. О. В. Потапчук, д-р мед. наук, проф. В. І. Паньків, д-р мед. наук, проф. Н. В. Скрипник, д-р мед. наук, проф. Н. I. Ярема, канд. мед. наук, доц. О. К. Мелеховець, канд. мед. наук, доц. Л. В. Наумова, канд. мед. наук, доц. Л. П. Мазур, канд. мед. наук, доц. І. П. Савченко, канд. мед. наук, доц. Л. В. Радецька, канд. мед. наук, асист. Л. М. Мігенько. В обов'язки журі входили перевірка та оцінювання завдань, визначення переможців та оголошення результатів, підготовка відповідної документації та нагородження переможців.

Оргкомітетом Всеукраїнської студентської олімпіади було розроблено основні завдання з дисципліни «Ендокринологія» на основі методичних рекомендацій щодо проведення Всеукраїнської студентської олімпіади [5].

Під час проведення олімпіади обробка персональних даних учасників була здійснена відповідно до Закону України «Про захист персональних даних» [6]. 
Кожен із студентів, які брали участь в олімпіаді з ендокринології, мав можливість виявити свої найсильніші сторони та досягнути певного успіхунагородження за певні завдання, або ж перемоги. Від студентів-учасників вимагався синтез знань з ендокринології, отриманих не лише за роки вивчення даної дисципліни у ВНЗ, але й суміжних дисциплін, таких, як кардіологія, фармакологія, лабораторна та інструментальна діагностика. Особливе місце в підготовці олімпійця з ендокринології займало вміння застосування стандартів семіотики та лікування при роботі з віртуальним пацієнтом.

Відбувався II етап студентської олімпіади у чотири тури. Першим туром було складання тестового контролю, яке мало на меті оцінити теоретичні знання кожного студента. Тестовий контроль як I тур олімпіади дав можливість виявити знання кожного учасника, простежити тенденції в навчальному процесі, виявити переваги та недоліки в опануванні дисципліни «Ендокринологія». Студенти мали можливість написати 100 тестових завдань протягом 100 хв у присутності постійнодіючої комісії викладачів ДВНЗ «Тернопільський державний медичний університет імені І. Я. Горбачевського МОЗ України» та членів журі. Оцінювання тестового контролю проводилося за бальною системою, тобто одна правильна відповідь прирівнювалася одному балу. Максимально можливий бал складав 100. Тестовий контроль як перший тур олімпіади дав можливість оцінити знання кожного учасника, а також виявити переваги та недоліки в оволодінні певними ендокринологічними нозологіями.

Другим туром студентської олімпіади з ендокринології було розв'язання ситуаційних задач (клінічних випадків із практики) підвищеної складності. Ситуаційна задача відображала конкретний клінічний випадок, який викладався стисло, але містив необхідну кількість інформації для встановлення діагнозу та можливості ефективно допомогти хворому. Виходячи з умов задачі, учасник олімпіади повинен був сформулювати також перелік діагностичних (лабораторних та інструментальних) методів для уточнення діагнозу, представити свою тактику надання допомоги на основі стандартів медикаментозної терапії.

Розв’язання ситуаційних задач дало можливість студенту проявити знання не лише з ендокринології, а й суміжних дисциплін, виділити провідний синдром, провести диференційну діагностику, застосувати максимально раціональну медикаментозну терапію у конкретного пацієнта на осно- ві даних доказової медицини, вибрати найбільш ефективні та безпечні лікарські засоби. Студенти мали можливість написати 5 ситуаційних задач із максимальною оцінкою 100 балів при умові часового обмеження 15 хв.

Для прикладу наводимо ситуаційну задачу з варіантом відповіді.

Ситуаційна задача 1. Хворий Б., 21 р., госпіталізований у терапевтичне відділення із скаргами на почащене сечовипускання (частота сечовипускання кожні 20 хв), виражену сухість у роті, спрагу, виражений біль спини, м'язову слабкість. Захворювання почалося гостро, після сильного переохолодження кілька днів тому. Об'єктивно: хворий нормальної тілобудови, задовільного живлення, виражене акне на обличчі та тулубі, відмічаються поодинокі стрії білуватого кольору на передній черевній стінці, пульс - 56 уд./хв, дихальна аритмія, AT 140/75 мм рт. ст. Межі відносної серцевої тупості зміщені вліво на 1 см, аускультативно серцева діяльність без патологічних змін. У легенях аускультативно ослаблене везикулярне дихання, шум тертя плеври справа. Лабораторні зміни: загальний аналіз сечі - пв - 1021, глюкоза 0,5 \%, ацетон (+), білок - сліди. Глюкоза плазми крові 24 ммоль/л, калій плазми крові - 2,8 ммоль/л, натрій - 141 ммоль/л, кортикотропін плазми 475,72 пг/мл (норма 7,9 66,1 пг/мл), кортизол плазми крові - 1280 нмоль/л (норма 18-650 нмоль/л). УЗД надниркових залоз: розмір правої надниркової залози - 20х30 мм, паренхіма однорідна, розмір лівої надниркової залози - 31х24 мм, паренхіма однорідна. МРТ гіпофіза: патологічних змін не виявлено. КТ органів грудної порожнини: у сегменті $\mathrm{S}_{10}$ справа пухлиноподібний утвір розміром 1 см у діаметрі. Рентгенологічно: виражений остеопороз хребців, компресійний перелом тіл хребців $\mathrm{L}_{1}, \mathrm{~L}_{3}$.

Мала дексаметазонова проба: вміст кортизолу в сироватці крові вихідний 1280 нмоль/л, після дексаметазонової проби - 850 нмоль/л.

Запитання:

1. Сформулюйте правильно попередній діагноз. Наведіть ваші міркування щодо патогенетичного зв’язку представлених даних. Які основні клінічні кластери (синдроми) можна виділити для постановки діагнозу?

2. Яке обстеження підтвердить можливий діагноз? Назвіть нозології для диференційного діагнозу.

3. Які клінічні особливості характерні для даного захворювання? 


\section{4. Яке лікування необхідно провести?}

5. Опишіть методику проведення та інтерпретацію малої та великої дексаметазонових проб.

\section{Еталони відповідей.}

1. Нейроендокринна пухлина легень. Синдром ектопічної секреції кортикотропіну (АКТГектопічний синдром). Стероїдний цукровий діабет. У хворого є АКТГ- ектопічний синдром, тобто пухлина в легені секретує АКТГ (будучи гормонально активною). Основними клініко-діагностичними ознаками, які дають змогу запідозрити АКТГектопічний синдром, є: акне, симптоми гіперглікемії, артеріальна гіпертензія, міастенія, підвищений рівень кортикотропіну та кортизолу плазми, гіпокаліємія, результати малої дексаметазонової проби, відсутність патологічних змін надниркових залоз та гіпоталамо-гіпофізарної зони.

2. Мала і велика дексаметазонові проби негативні. Проба із десмопресином $\epsilon$ негативна. Десмопресинова проба використовується для диференціації із хворобою Іценка - Кушинга, при якій після введення десмопресину відзначається підвищення АКТГ. Після хірургічного видалення пухлини використовують фарбування із АКТГ-специфічними маркерами, що дає змогу диференціювати АКТГсекретуючі клітини.

Гіпоталамічний синдром, синдром Іценка - Кушинга, хвороба Іценка - Кушинга.

3. Для АКТГ-ектопічного синдрому не характерне ожиріння; рівень АКТГ, як правило, значно збільшений, виражена гіпокаліємія, мала і велика дексаметазонова проби негативні.

4. Оперативне лікування: видалення пухлини. Інсулінотерапія для лікування цукрового діабету. Лікування кетозу. Корекція гіпокаліємії.

5. Мала дексаметазонова проба проводиться у двох варіантах: 1) спочатку визначають добову екскрецію вільного кортизолу, потім протягом двох діб хворий приймає по 0,5 мг дексаметазону кожні 6 год. На другу добу прийому оцінюють добову екскрецію вільного кортизолу; 2) визначають добову екскрецію вільного кортизолу, хворий приймає 1 мг дексаметазону між 11 та 12 год ночі та визначають кортизол між 8 та 9 год наступного ранку. У здорових людей або при наявності функціонального гіперкортицизму після прийому дексаметазону екскреція кортизолу знижується на 50 \% і більше, а при хворобі Іценка - Кушинга подібного зниження не відбувається.

Велика дексаметазонова проба дозволяє віддиференціювати різні види патологічного гіперкор- тицизму. Спочатку визначають добову екскрецію вільного кортизолу, потім протягом двох діб хворий приймає по 2 мг дексаметазону кожні 6 год. На другу добу прийому оцінюють добову екскрецію вільного кортизолу. При хворобі Іценка - Кушинга рівень кортизолу знижується на 50 \% і більше, а при АКТГ-ектопованому синдромі або АКТГнезалежному гіперкортицизмі наднирниковозалозного походження зниження не відбувається.

Третім туром Всеукраїнської студентської олімпіади 3 ендокринології було вирішення змодельованого невідкладного стану в інтерактивному режимі. Студенту було запропоновано роботу із симуляційним пацієнтом за допомогою інтерактивної дошки. Кожна симуляція була розроблена згідно з клінічним випадком з дисципліни «Ендокринологія». На екрані інтерактивної дошки було представлено віртуального пацієнта із можливістю збору повного спектра скарг, анамнезу фізикальних та лабораторно-інструментальних обстежень, а також призначення відповідної терапії із вказанням конкретних доз препаратів.

Робота олімпійця біля ліжка віртуального пацієнта дала можливість ознайомитися 3 повним спектром ендокринологічної патології. На даному етапі олімпіади було оцінено вміння збирати скарги, з'ясовувати анамнез захворювання та життя, методично правильно проводити огляд пацієнта та оцінювати загальний стан, здійснювати фізикальне обстеження серцево-судинної, дихальної, травної та інших систем організму. Саме тут зверталась увага на вміння та знання з ендокринології, вміння виділяти провідний синдром та поєднувати його з анамнезом захворювання, а також швидкість та оперативність у вирішенні даного завдання.

Завершальним, четвертим, туром олімпіади було вирішення практичних завдань 3 інтерпретації лабораторно-інструментальних методів обстеження. На даному етапі зверталась увага на вміння інтерпретувати результати лабораторних та інструментальних методів обстеження у конкретного пацієнта (біохімічний аналіз крові, гормональний фон, комп'ютерна томографія або магнітно-ядерний резонанс). Усі студенти мали однотипне завдання гіпоглікемічний стан із часовим обмеженням 12 хв та максимально можливим балом 100.

Після проходження усіх турів олімпіади журі було проведено підбиття підсумків II етапу Всеукраїнської студентської олімпіади з ендокринології. Урочисте нагородження учасників проводили голова організаційного комітету та голова журі в 
заключний день олімпіади. Були визначені призери у кожному з турів олімпіади. За кількістю набраних балів у II етапі Всеукраїнської студентської олімпіади з ендокринології переможцями стали учасники із Тернопільського державного медичного університету ім. І. Я. Горбачевського (І місце), Івано-Франківського національного медичного університету і Сумського державного медичного університету (II місце) та Львівського національного медичного університету ім. Д. Галицького, Київського медичного університету і Дніпропетровської медичної академії (III місце).

Висновки та перспективи подальших досліджень. Таким чином, Всеукраїнська студентська олімпіада з ендокринології, яка відбулася 4-5 квітня 2019 р. в м. Тернополі, стала важливим етапом у підготовці висококваліфікованих спеціалістів, ефективним способом набуття нових практичних знань та навичок, а також демонстрації вмінь самовдосконалення.

Проведення II етапу Всеукраїнської студентської олімпіади з ендокринології об’єднує та мобілізує студентів з усіх куточків України з багатьох вищих медичних навчальних закладів. Окрім цього, підготовка до олімпіади формує високий професійний та інтелектуальний рівень студентів, надихає їх до самоорганізації та самореалізації, підвищує медичну освіченість нашої молоді.

\section{Список літератури}

1. Береснев А. Д. Система вимог до методичного, програмного та організаційного забезпечення олімпіад [Електронний ресурс] / А. Д. Береснев // Телематика.2003. - Режим доступу : www.ict.edu.ru.

2. Бернвальд Т. Формування мотивації навчальної діяльності майбутніх вчителів в умовах сьогодення / Т. Бернвальд // Рідна школа. - 2011. - № 11. - С. 60-64.

3. Вакалюк І. П. Методологічні аспекти проведення студентської предметної олімпіади з дисципліни «Внутрішня медицина» / І. П. Вакалюк, Н. М. Середюк, В. Н. Середюк // Медична освіта. - 2015. - № 4. - С. 83-86.

4. Лузік Е. В. Організація наукової діяльності студентів вищих навчальних закладів / Е. В. Лузік // Педагогіка і психологія професійної освіти: результати досліджень

\section{References}

1. Beresnev, A.D. (2003). Systema trebovaniy k metodycheskomu, programmnomu i organizatsyonnomu obespecheniyu Internet-olimpiad [The system of requirements for methodological, program and organizational support of Internet Olympiads]. Proceedings of the X All-Ukrainian
Аналіз знань та вмінь студентів дозволив викладачам акцентувати увагу на обговоренні проблемних питань ендокринології та у вирішенні складних завдань, що в результаті забезпечить підвищення якості викладання ендокринології в інших вищих навчальних закладах.

Окрім традиційних етапів олімпіади, таких, як тестовий контроль, розв'язання ситуаційних задач та інтерпретація лабораторно-інструментальних методів обстеження, надзвичайно ефективним та динамічним $€$ тур із вирішенням змодельованого невідкладного стану в інтерактивному режимі.

Всеукраїнська олімпіада з ендокринології сприяє активізації розвитку та втілення здібностей й навчально-пізнавальної діяльності студентів, заохочування їх до глибшого вивчення дисципліни «Ендокринологія», а також заохочує науково-педагогічних працівників до виявлення та відбору обдарованої молоді та підвищення якості підготовки майбутніх медиків.

У перспективі - оптимізація якості проведення II етапу Всеукраїнської студентської олімпіади 3 ендокринології шляхом формування креативного клінічного мислення студентів на основі не лише традиційних теоретичних знань та практичних навичок, але й застосування сучасних інтерактивних комп’ютерних технологій та методів візуалізації.

і перспективи : зб. наук. праць / за ред. I. А. Зазюна та Н. Г. Ничкало. - К., 2003. - С. 380-395.

5. Методичні рекомендації щодо проведення Всеукраїнської студентської олімпіади // Наказ Міністерства освіти і науки України № 1324 від 18.11.2011 р. [Електронний ресурс]. - Режим доступу : http:// dmee. ru/docs/100/index-2764.html.

6. Про захист персональних даних : Закон України від 27.03.2014 р. № 1170 -VII [Електронний ресурс]. - Режим доступу : http // zakon4.rada.gov.ua/laws/show/2297-17. 7. Слухенська Р. В. Формування творчого потенціалу майбутніх лікарів у процесі професійної підготовки : автореф. дис. на здобуття наук. ступеня канд. пед. наук / Р. В. Слухенська. - 3., 2016. - 21 с.

Scientifically Methodical Conference “Telematyka'2003”. Retrieved from: http://www.ict.edu.ru [in Russian].

2. Bernvald, T. (2011). Formuvannia motyvatsii navchalnoi diialnosti maibutnikh vchyteliv v umovakh sohodennia [The formation of the motivation for the scientific activity the 
teachers in future in the condition of present]. Ridna shkola - The Native School, 11, 60-64 [in Ukrainian].

3. Vakaliuk, I.P., Serediuk, N.M., \& Serediuk, V.N. (2015). Metodolohichni aspekty provedennia studentskoi predmetnoi olimpiady z dystsypliny “Vnutrishnia medytsyna” [Methodological aspects of conducting student subject Olympiad in the discipline "Internal Medicine"]. Medychna osvita - Medical Education, 4, 83-86 [in Ukrainian].

4. Luzik, E.V. (2003). Orhanizatsiia naukovoi diialnosti studentiv vyshchykh navchalnykh zakladiv. Pedahohika i psykholohiia profesiinoi osvity: rezultaty doslidzhen $i$ perspektyvy: zb. nauk. prats [Organization of scientific activity of students of higher educational institutions. Pedagogy and psychology of vocational education: research results and perspectives: Coll. of Scient. Works]. Zaziun, I.A., \& Nychkalo, N.H. (Eds.). Kyiv [in Ukrainian].
5. (2011). Metodychni rekomendatsii shchodo provedennia Vseukrainskoi studentskoi olimpiady [Methodical recommendations for holding the All-Ukrainian Student Olympiad]. Nakaz Ministerstva osvity i nauky Ukrainy № 1324 - The Law of the Ministry of Education and Science of Ukraine No. 1324. Retrieved from: http://dmee.ru/docs/100/ index-2764.html.

6. Zakon Ukrainy "Pro zakhyst personalnykh danykh" [Law of Ukraine “On Protection of Personal Data”]. Retrieved from: https://zakon.rada.gov.ua/laws/show/2297-17. 7. Sluhenska, R.V. (2016). Formuvannia tvorchoho potentsialu maibutnikh likariv u protsesi profesiinoi pidhotovky [Formation of creative potential of future doctors in the process of professional training]. Extended abstract of Candidate's thesis. Zaporizhzhia [in Ukrainian].

Електронна адреса для листування: pasyechko@tdmu.edu.ua 